УДК 338:351.72

DOI: https://doi.org/10.32689/2618-0065-2020-2(4)-149-159

Заблоцька Анастасія Вікторівна, аспірантка, Національна академія державного управління при Президентові України, Київ, вул. Ежена Потьє, 20, 02000, Україна, тел.: (044)-481-2155, e-mail: ana.zablotska@gmail.com, https://orcid.org/0000-0002-5904-8493

\title{
ДЕЦЕНТРАЛІЗАЦІЙНІ РИЗИКИ У ПИТАННІ ФІНАНСУВАННЯ ЗАКЛАДІВ ОСВІТИ УКРАЇНИ
}

Анотація. Питання децентралізації влади та створення об'єднаних територіальних громад нині є чи не найбільш обговорюваними як у засобах масової інформації, так і в середовищі науковців та практиків. У процесі реалізації реформи об'єднані територіальні громади отримали нові повноваження, але разом з ними і старі, роками не вирішені проблеми. Здебільшого небажання брати на себе відповідальність та зневіра в успішній реалізації реформ гальмують процеси децентралізації, викликають несприйняття як з боку «старої» влади, так і з боку населення. Проблемами $є$ й прогалини у законодавчому забезпеченні вирішення низки нагальних питань, відсутність управлінського досвіду як на місцевому, так і загальнодержавному рівнях. Отже, реформування часто відбувається на основі «спроб і помилок». Створення об'єднаних територіальних громад має започаткувати нову парадигму в управлінні не лише на місцевому рівні, але й у державі загалом, що у кінцевому підсумку має стати підгрунтям для відчутного поліпшення якості життя населення. У статті розглянуто теоретичні засади децентралізації в Україні та децентралізації в освіті зокрема, нормативно-правову базу впровадження головної реформи останніх років. Визначено концептуальні засади реформування в освіті та державної освітньої політики, основу демократизації управління закладами освіти. Надано оцінку проміжним результатам й успішності впровадження реформи за кількісними (кількість утворених громад) та якісними (фінансова спроможність громад) показниками. Проаналізовано узгодженість запровадження законодавства щодо створення спроможних об'єднаних громад та мережі опорних закладів освіти. Здійснено підрахунок фінансової спроможності ОТГ для утримання й розвитку освітньої сфери, а також співставлення запланованого фінансування сфери освіти в обласному та державному бюджетах. Розглянуто критичні ситуації, які уже виникали в процесі децентралізації освіти, а також їх причини та наслідки. Окреслено ризики децентралізації у процесі диверсифікації фінансування чи розбудови фінансової спроможності закладів освіти в ОТГ. 
Ключові слова: децентралізація, освітня політика, заклади освіти, реформа, рейтингування освіти, фінансова спроможність, бюджети.

Zablotska Anastasiia Viktorivna, postgraduate student, National Academy of Public Administration under the President of Ukraine, Kyiv, st. Ezhena Pot'ye, 20, 02000, Ukraine, tel.: (044)-481-2155, e-mail: ana.zablotska@gmail.com, https://orcid.org/0000-0002-5904-8493

\section{DECENTRALIZATION RISKS FOR THE FINANCING OF EDUCATION INSTITUTIONS OF UKRAINE}

Abstract. The issue of decentralization of power and the creation of united territorial communities are nowadays the most talked about in the media as well as among scholars and practitioners. In the course of the reform implementation, the united territorial communities were given new powers, but with them, the old, old years had not been resolved. For the most part, the reluctance to take responsibility and the disillusionment with the successful implementation of reforms hinder the processes of decentralization and cause rejection both by the "old" authorities and by the population. Problems are gaps in the legislative support to address a number of urgent issues, lack of management experience at both local and national levels. Thus, reform is often based on trial and error. The creation of united territorial communities should launch a new paradigm in governance not only at the local level, but also in the state as a whole, which should ultimately be the basis for a tangible improvement in the quality of life of the population. The article discusses the theoretical principles of decentralization in Ukraine and decentralization in education, in particular, the legal framework for the implementation of major reform in recent years. The conceptual bases of reformation in education and state educational policy, the basis of democratization of management of educational establishments are defined. The interim results and the success of the implementation of the reform were evaluated by quantitative (number of communities formed) and qualitative (financial capacity of communities) indicators. The coherence of the implementation of the legislation on creation of able united communities and a network of educational support institutions is analyzed. The financial capacity of the united territorial communities for the maintenance and development of the educational sphere has been calculated, as well as the comparison of the planned financing of the education sector in the regional and state budgets. Critical situations that have already arisen in the process of decentralization of education, as well as their causes and consequences are considered. The risks of decentralization in the process of diversification of financing or capacity building of educational institutions in the united communities are outlined. 
Keywords: decentralization, educational policy, educational institutions, reform, education rating, financial capacity, budgets.

Постановка проблеми. 32014 року в Україні розпочався процес децентралізації. Ухваливши Концепцію реформування місцевого самоврядування, Уряд започаткував низку реформ, які забезпечують загалом передачу повноважень та фінансів від державної влади якнайближче до людей - органам місцевого самоврядування. В тому числі реформа адміністративна, фінансова та освітня.

Конституційні засади місцевого самоврядування знайшли відображення у законодавчо-правових актах, зокрема: в Законі України «Про співробітництво територіальних громад» (2014, № 34, ст.1167) визначено організаційно-правові засади співробітництва територіальних громад, принципи, форми, механізми такого співробітництва, його стимулювання, фінансування та контролю. Співробітництво грунтується на принципах: законності, добровільності, взаємної вигоди, прозорості та відкритості, рівноправності учасників, взаємної відповідальності суб'єктів співробітництва за його результати (стаття 2 цього закону). У Концепції реформування місцевого самоврядування та територіальної організації влади в Україні, затвердженої розпорядженням Кабінету Міністрів України 2014 р. № 333-р., Законі України «Про засади державної регіональної політики» (2015, № 13, ст.90) визначено основні правові, економічні, соціальні, екологічні, гуманітарні та організаційні засади державної регіональної політики. Закон України «Про добровільне об'єднання територіальних громад» $(2015$, № 13 , ст.91) регулює відносини, що виникають у процесі добровільного об'єднання територіальних громад сіл, селищ, міст, а також добровільного приєднання до об'єднаних територіальних громад із дотриманням принципів конституційності та законності, добровільності, економічної ефективності, державної підтримки, повсюдності місцевого самоврядування тощо [1].

Концептуальними засадами реформування в освіті та державної освітньої політики в умовах децентралізації слугують Закон України «Про освіту» (2017 № 2145-VIII ), що «регулює суспільні відносини, які виникають у процесі реалізації конституційного права людини на освіту, прав та обов'язків фізичних і юридичних осіб, які беруть участь у реалізації цього права, а також визначає компетенцію державних органів та органів місцевого самоврядування у сфері

освіти»; Концепція реалізації державної політики у сфері реформування загальної середньої освіти «Нова українська школа» на період до 2029 року та іншими нормативно-правовими актами, в яких пріоритетним завданням визначено демократизацію, децентралізацію управління освітою, перехід до децентралізованої державно-громадської моделі управління в сфері освіти [2].

Державна політика України у сфері місцевого самоврядування спирається на інтереси жителів територіальних громад. В основу цієї політики закладено 
положення Свропейської хартії місцевого самоврядування та найкращі світові стандарти суспільних відносин у цій сфері.

У межах політичної демократизації та децентралізації влади в Україні відбувається децентралізація управління освітою шляхом переходу від централізованого управління мережею дошкільних і шкільних закладів освіти та передачі відповідальності за них місцевим органам громадського самоврядування; активного створення об'єднаннях територіальних громад (ОТГ), освітніх округів та опорних закладів освіти для рівного доступу усіх дітей до якісної освіти, раціонального і ефективного використання ресурсів.

Метою статті є децентралізації під час освітньої реформи $є$ зміна підходу до фінансування освіти: в результаті реформи розподіл коштів відбувається не на навчальний заклад, а в розрахунку на кожного учня. Крім цього, децентралізація цього сектору прагне до забезпечення однакового доступу до якісної середньої освіти усіх жителів України в будь-якому куточку, як в маленькому селі, так і в місті.

Аналіз останніх досліджень і публікацій. Питання реформування публічного управління та децентралізації влади, формування соціальної політики держави $є$ предметом розгляду багатьох як вітчизняних учених (О. Батанов, О. М. Безпалько [3], М. І. Грицяк, М. Долішній, І. Коліушко, О. Копиленко, В. Кравченко, А. Лелеченко, С. Максименко, В. Мархлєвскі [4], Н. Нижник, I. Пахомов, Н. Плахотнюк, О. Прієшкіна, С. Романюк, М. Харитончук та ін.), так і зарубіжних (М. Войцех [5], О. Гуменна [6], Я. Герчинський, М. Кітінг, С. Ліпсет, В. Мархлевскі М. Портер, В. Роккан, П. Сегварі, Е. Томпсон та ін.).

Особливості реформування освіти, в т.ч. процеси децентралізації в управлінні освіті $є$ предметом наукових досліджень таких вітчизняних учених, як Л. Гаєвська, Л. Калініна [7], Т. Лукіна, Л. Паращенко, І. Семнець-Орлова, М. Топузов, Р. Шиян [8] та ін. Децентралізація управління освітою є одним із механізмів реформування системи загальної середньої освіти й упорядкування освітньої мережі в країні. В наукових працях розкриті різні аспекти організаційно-правових засад децентралізації влади в освіті. Водночас ще бракує наукових досліджень особливостей формування освітніх мереж в об'єднаних територіальних громадах та управління ними в умовах децентралізації.

Виклад основного матеріалу. Процеси децентралізації в Україні сприяли розвитку місцевого самоврядування та позитивній тенденції створення об'єднаних територіальних громад із центрами у містах обласного значення упродовж 2016-2019 рр. За 9 місяців 2016 року було створено159 ОТГ, кількість яких у березні 2017 року становила 413, а станом на початок 2019 року зросла до 878 ОТГ. «До складу цих об'єднаних територіальних громад увійшли 4018 колишніх місцевих рад. 9 млн. людей проживають в ОТГ. Такі 
темпи міжмуніципальної консолідації міжнародні експерти називають дуже високими» [9].

Проте запровадження законодавства щодо створення спроможних об'єднаних громад та мережі опорних закладів освіти грунтуються на різних принципах та абсолютно неузгоджені адміністративно. Добра ціль часто нівелюється за відсутності досконалого законодавства та ефективного управління. Адже, наприклад, опорна школа (продукт одного закону), що потребує сталого фінансування та постійної організаційної підтримки, знаходиться у дотаційній об'єднаній територіальній громаді (продукт іншого закону тої ж концепції), не може розвиватися і досягати поставленої амбітної мети [10].

Незважаючи на успішні приклади передачі повноважень, процес децентралізації та передачі повноважень на місця рухається доволі повільно. Станом на 10 травня 2018 року, в Україні було створено 731 ОТГ. Усього буде створено понад 1200 ОТГ, хоча точна кількість наразі невідома - це залежить від місцевих жителів та місцевої влади, проте майже 50\% території України все ще вільне від ОТГ [9] Але є й унікальні успішні практичні приклади громад, де завдяки вдалому менеджменту змогли вдало поєднати результати реформ у різних сферах децентралізаційної політики.

23 січня 2019 року було започатковано новий етап реформи децентралізації, ініційований Кабінетом Міністрів України (Розпорядження «Про затвердження плану заходів з реалізації нового етапу реформування місцевого самоврядування та територіальної організації влади в Україні на 2019-2021 роки» №77-p), який передбачає закріплення вже набутих успіхів і завершення формування спроможних громад, зміну територіального устрою, чітке розмежування повноважень та функцій контролю різних рівнів управління, а також розвиток форм місцевої демократії. Відповідно до нового етапу реформи децентралізації, передбачається формування 100 спроможних районів та 1600-1800 спроможних громад, наслідком чого стане закріплення фінансової самодостатності місцевого самоврядування; формування ефективної системи управління; упорядкування системи державного контролю.

Звертаючи увагу на фінансові показники, які визначені у Законі України «Про державний бюджет України на 2020 рік» [11], а особливо Додаток №5, можемо зробити очевидні висновки. У бюджеті 2020 року всього 1442 об'єкти прямих міжбюджетних відносин (прямі міжбюджетні трансферти). 859 з цих об'єктів - це уже створені об'єднані громади. Лише 234 об'єкти, вказані в бюджеті, мають реверсну дотацію і є фінансово спроможними, і це лише $27 \%$ із загального переліку.

Якщо переглянемо ОТГ Київської області, яка вважається найбагатшою, найприбутковішою та найефективнішою, то ситуація викликатиме стурбування. За підрахунками виходить, що 20 затверджених об'єднаних 
громад Київської області, які вже включені у державний бюджет країни 2020 року для прямих міжбюджетних відносин, усі 100\% дотаційні. А обласна адміністрація рахує спроможність громад по рівню ПДФО, не враховуючи, що витрати на утримання інфраструктури (садочки, школи, лікарні тощо) та побудови нових об’єктів абсолютно не під силу цим громадам. Тобто вони неспроможні фінансово до самостійного розвитку.

Зважаючи на це, можемо припустити, що усі 39 опорних заклади освіти (3 філіями) Київської області у $100 \%$ випадків знаходяться в дотаційних громадах. Це означає, що в громад навіть не достатньо коштів на заробітні плати (садочки, центри розвитку) та оплату комунальних послуг в освітніх закладах. А за середніми статистичними даними, фінансування усієї мережі закладів освіти однієї громади відбувається на сьогодні за пропорцією: 50\% субвенція, 50\% - місцеві бюджети (садочки, комунальні платежі, доплати до зарплат в школах). Питання чи буде громада ставити в пріоритет розвиток освіти, доплати педагогам та закупівлю шкільних автобусів, замість будівництва доріг й створенню благоустрою в населених пунктах залишається відкритим [12-15].

Політика Уряду та загалом реформа децентралізації спрямована на те, щоб утворені об'єднані громади самостійно за рахунок місцевих податків та зборів, а також інвестиційних проектів, могли утримувати себе і розвивати свою інфраструктуру. За реформою щороку субвенції планують урізатися. Розглянемо, що потребує передбачено до фінансування освіти у 2020 році згідно затвердженого бюджету.

Також Уряд визначив пріоритетні напрямки (проблеми) для фінансування, що має значно збільшити якість освітніх послуг на місцях [16-17]:

- неможливість в малокомплектних школах організувати якісний освітній процес;

- проблема $з$ дорогами;

- фінансові витрати на утримання малокомплектних шкіл;

- застаріла матеріально-технічна база шкіл.

Окремо було розглянуто пріоритети фінансування для розвитку дошкілля, і вони є дуже значними й затратними:

- відкриття новобудов;

- відкриття додаткових груп;

- реконструкція;

- створення дошкільних відділень у закладах освіти;

- відкриття приватних ЗДО;

- відновлення ЗДО, що використовувалися не за призначенням;

- ЗДО у пристосованих приміщеннях;

- групи короткотривалого перебування;

- прогулянкові групи;

- групи вихідного дня. 
В Україні вже створено 806 опорних шкіл. Коштів, які передбачені Урядом для покращення ситуації в школах, вистачить здебільшого лише на ці опорні заклади. Інші 16000 шкіл - залишаються фактично на звичайній субвенції 3 розрахунком на підтримку спроможної громади. Це легко обраховується із таких даних:

- 3,5 млрд. грн. - «Спроможна школа для кращих результатів»;

- 1,4 млрд. грн. - Нова українська школа;

- 801 млн. 624,0 тис. грн. - STЕМ-лабораторії;

- 600 млн. грн. - придбання шкільних автобусів;

- 400 млн. грн. - обладнання для їдалень;

- 55 млн. 335,4 тис. грн. - програма «Гідність дитини»;

- 44 млн. 272,0 тис. грн. - обладнання для спеціальних шкіл;

- 504,5 млн. грн.. - субвенція на інклюзію;

- 259 млн. грн. - кошти на НПЦ.

Розглянемо бюджет Київської області в розрізі освіти на 2019 та 2020 роки. У 2019 році на освіту було виділено 783 млн. грн., у 2020 трохи більше - 862 млн. грн. Проте чи покривають ці 80 млн. усі фінансово неспроможні громади - викликає сумніви. Для порівняння, місто Ірпінь на освіту місцевих закладів у 2019 році витратив 60 млн. грн. з міського бюджету, і цього було не достатньо для відчутного покращення освітніх умов у місті. 3 цього робимо припущення, що 80 млн. грн. на область $\epsilon$ абсолютно недостатніми [18-19].

У питанні фінансування закладів освіти в ОТГ, основною територією яких $\epsilon$ села, $є$ багато ризиків. Ці ризики накладаються на ті додаткові потреби у підтримці шкіл невеликих населених пунктах, що демонструють і без того низьку якість і результативність надання освітніх послуг. Цю проблему беззаперечно висвітлюють результати зовнішнього незалежного оцінювання навчальних досягнень випускників шкіл упродовж останніх років [20].

Також варто згадати складну ситуацію, яка склалася з 2016 року. Згідно рішення Уряду у рамках децентралізації навчальні плани, вказівки щодо набору студентів, а також інші накази-рекомендації надходили до професійнотехнічних училищ 3 Києва, а кошти на життєзабезпечення закладів профтехосвіти мали виділятися 3 місцевих бюджетів. Проблеми $\mathrm{i}$ досі спостерігаються з систематичними невиплатами заробітних плат викладачам, величезні борги за комунальні послуги, суттєве зниження надання освітніх послуг у цих закладах.

Наприклад, Житомирська міська рада в тій ситуації мусила замислитися над тим, де ж віднайти для потреб десяти ПТУ, які навчають учнів у обласному центрі, щонайменше 80 мільйонів гривень. У Бердичеві для потреб трьох ПТУ міський бюджет повинен був передбачити щонайменше 22 мільйони гривень на рік. У Малині, Коростені та Новограді-Волинському ситуація такою складною не видавалася (у кожному з цих міст розміщено по одному ПТУ), 
однак і можливості їхніх місцевих бюджетів сьогодні не можна назвати занадто потужними. Ці ж самі проблеми не оминули майже кожне більш-менш велике місто в усіх областях України. Міст, які можуть собі дозволити профінансувати ПТУ, не багато. Тому Уряд розглянув можливість у 2022 році повернути фінансування ПТУ на обласні бюджети [21].

Ми знаємо, що завдяки щоденному спілкуванню з місцевою спільнотою працівники школи розуміють специфічні потреби і зацікавлення учнів, тож здатні вибрати такі методи навчання, які найкраще їм підходять. Автономні школи будуть також здатні найоптимальніше використовувати свої специфічні ресурси, зокрема, унікальні навики окремих вчителів. Проте автономію в сучасних умовах потрібно впроваджувати обережно й зважено, і головним чином - саме у фінансовій сфері.

Висновки. Для системи загальної середньої освіти в Україні децентралізація - це шанс порвати із комуністичним минулим, підвищити ефективність використання коштів та загалом можливість їх автономно залучати кошти для свого розвитку. I, оскільки успішність реформи можлива лише за умови, коли всі гравці є сильними, то важливим $є$ фактор побудови сильного і незалежного місцевого самоврядування. А в умовах слабкої фінансової спроможності, яку ми спостерігаємо на сьогодні в новоутворених ОТГ, виникає багато ризиків розвитку якості освіти в ОТГ. Відтак, державне управління в сфері освіти та освітня політика загалом, мають фокусуватися на тому, що, по-перше, процес переводу закладів освіти на фінансування 3 місцевих джерел має бути поступовим, нестрімким та за умови узгодження нормативно-правової бази реформування адміністративно-територіального устрою 3 реформуванням освіти. По-друге, сильним гравцем у процесі децентралізації та посилення автономії закладу повинен стати директор школи, що стане більш ефективним менеджером, добре підготовленим до свого фаху, компетентним не тільки у сфері дидактики, а і в управлінні фінансами. Подальшого дослідження та наукового обгрунтування потребують процеси управління фінансуванням закладів освіти в об'єднаних територіальних громадах України.

\section{Jimepamypa:}

1. Актуальні проблеми шкільної освіти в Україні. Урядовий кур'єр. 2017. URL : https://ukurier.gov.ua/uk/articles/aktualni-problemi-shkilnoyi-osviti-v-ukrayini/.

2. Про освіту: Закон України від 05.09.2017 № 2145-VIII / Офіційний вісник України. 2017. URL : https://zakon.rada.gov.ua/laws/show/2145-19.

3. Шарлея Р., Кавунець А. В., Безпалько О. М., Москалу М., Ланова А. І. Європейські стратегії для місцевих громад України та Молдови: досвід країн Вишеградської четвірки: методичний посібник. Вінниця: ТОВ «Нілан-ЛТД», 2018. 76 с.

4. Сеїтосманов А., Фасоля О., Мархлєвскі В. Нова школа у нових громадах : посібник з ефективного управління освітою в об'єднаних територіальних громадах. Київ, 2017. 128 с.

5. Войцех М., Процак О. Стратегія розвитку освіти в громаді : практичний порадник. Київ, 2018. 56 с. 
6. Управління системою освіти територіальних громад: досвід країн Вишеградської четвірки для України: методичний посібник із збіркою кращих практик / А. Кавунець, А. Ланова, О. Гуменна та ін. Вінниця : ТОВ «Твори», 2018. 120 с.

7. Калініна Л. М., Топузов О. М. Аналіз базових засад управління опорним закладом освітнього округу. Комп ’ютер у школі та сім'ї. 2018. № 3. С. 21-27.

8. Шиян Р. Децентралізація освіти у Польщі: досвід для України. Київ, 2016. 44 с.

9. До уваги ОТГ: індекс спроможності шкільної освітньої мережі. URL : https://decentralization.gov.ua/news/8889.

10. Конституція України: закон України від 28 червня 1996 р. № 254к/96 / Верховна Рада України. URL : https://zakon.rada.gov.ua/laws/show/254\%D0\%BA/96-\%D0\%B2\%D1\%80.

11. Про державний бюджет України на 2020 рік : Закон України від 03.04.2020 / Відомості Верховної Ради України. URL : https://zakon.rada.gov.ua/laws/show/294-20.

12. Механізм розподілу додаткової дотації на утримання закладів освіти та охорони здоров'я в областях: погляд експерті. URL : https://decentralization.gov.ua/news/8790.

13. Демографічна криза та нерівність в українській шкільній системі. Шкільна карта України. URL : https://cedos.org.ua/edustat/graph.

14. European commission, 2018. Key competences. European Commission: Education and Training. URL : https://ec.europa.eu/education/policy/school/competences_en.

15. OECD, 2018. Education attainment - Adult education level - OECD Data. OECD. URL : http://data.oecd.org/eduatt/adult-education-level.htm.

16. Єдиний веб-портал органів виконавчої влади України. URL : https://www.kmu.gov.ua.

17. Державна політика, законодавчі напрацювання, проміжні результати першого етапу децентралізації влади в Україні. URL : https://decentralization.gov.ua/about.

18. Про обласний бюджет Київської області на 2019 рік : Рішення Київської обласної ради від 20.12.2018 № 530-25-VII. URL : http://koda.gov.ua/oblderzhadministratsija/publichnainformatsiya/byudzhet-kiivskoi-oblasti/rishennya-pro-oblasniy-byudzhet-kiivsk/2019-rik/.

19. Методичні рекомендації щодо створення системи управління освітою об'єднаних територіальних громад. URL : https://old.decentralization.gov.ua/pics/attachments/2016-02-221.pdf.

20. Про схвалення проєкту рішення Київської обласної ради "Про обласний бюджет Київської області на 2020 рік" : Розпорядження Голови Київської обласної адміністрації від 22.11.2019. №678. URL : http://koda.gov.ua/normdoc/pro-skhvalennya-proiektu-rishennya-kiivs/.

21. Про місцеве самоврядування в Україні : Закон України від 21.05.1997 № 280/97-ВР / Відомості Верховної Ради України. URL : https://zakon.rada.gov.ua/laws/show/280/97$\% \mathrm{D} 0 \% \mathrm{~B} 2 \% \mathrm{D} 1 \% 80$.

\section{References:}

1. Aktualni problemy shkilnoi osvity $\mathrm{v}$ Ukraini [Actual problems of school education in Ukraine]. (2017). ukurier.gov.ua. Retrieved from https://ukurier.gov.ua/uk/articles/aktualniproblemi-shkilnoyi-osviti-v-ukrayini/ [in Ukrainian].

2. Zakon Ukrainy "Pro osvitu” : vid 05.09.2017, № 2145-VIII [Law of Ukraine "On education” from 05.09.2017, № 2145-VIII]. (2017). Ofitsiinyi visnyk Ukrainy - Official Bulletin of Ukraine, 38-39. Art. 380. Retrieved from https://zakon.rada.gov.ua/laws/show/2145-19 [in Ukrainian].

3. Sharleia, R., Kavunets, A. V., Bezpalko, O. M., Moskalu, M., Lanova, A. I. (2018). Yevropeiski stratehii dlia mistsevykh hromad Ukrainy ta Moldovy: dosvid krain Vyshehradskoi chetvirky [European strategies for the local communities of Ukraine and Moldova: experience of the Visegrad countries]. Vinnitsa: TOV «Nilan-LTD» [in Ukrainian].

4. Seitosmanov, A., Fasolia, O., Markhlievski, V. (2017). Nova shkola u novykh hromadakh: posibnyk z efektyvnoho upravlinnia osvitoiu vobiednanykh terytorialnykh hromadakh [New School 
in New Communities: A Guide to Effective Governance in United Territorial Communities]. Kyiv [in Ukrainian].

5. Voitsekh, M., Protsak, O. (2018). Stratehiia rozvytku osvity v hromadi [A strategy for the development of community education]. Kyiv [in Ukrainian].

6. Kavunets, A., Lanova, A., Humenna, O., et al. (2018). Upravlinnia systemoiu osvity terytorialnykh hromad: dosvid krain Vyshehradskoi chetvirky dlia Ukrainy: metodychnyi posibnyk iz zbirkoiu krashchykh praktyk [Management of the system of education of territorial communities: experience of the Visegrad Four countries for Ukraine: a methodological guide with the collection of best practices]. Vinnitsa: TOV «Tvory» [in Ukrainian].

7. Kalinina, L.M., Topuzov, O.M. (2018). Analiz bazovykh zasad upravlinnia opornym zakladom osvitnoho okruhu [Analysis of the basic principles of management of the educational institution]. Kompiuter u shkoli ta simi-Computer at school and family, 3, 21-27 [in Ukrainian].

8. Shyian, R. (2016). Detsentralizatsiia osvity u Polshchi: dosvid dlia Ukrainy [Decentralization of education in Poland: experience for Ukraine]. Kyiv [in Ukrainian].

9. Do uvahy OTH: indeks spromozhnosti shkilnoi osvitnoi merezhi [ATG Note: School Capability Index of the School Education Network]. (2018). decentralization.gov.ua. Retrieved from https://decentralization.gov.ua/news/8889 [in Ukrainian].

10. Konstytutsiia Ukrainy : vid 28 chervnia 1996 roku [Constitution of Ukraine from June 28, 1996]. (1996). Vidomosti Verkhovnoi Rady Ukrainy - Bulletin of Verkhovna Rada of Ukraine, 30. Art. 141. Retrieved from https://zakon.rada.gov.ua/laws/show/254\%D0\%BA/96$\% \mathrm{D} 0 \% \mathrm{~B} 2 \% \mathrm{D} 1 \% 80$ [in Ukrainian].

11. Zakon Ukrainy "Pro derzhavnyi biudzhet Ukrainy na 2020 rik" : vid 03.04.2020 [Law of Ukraine "On the State Budget of Ukraine for 2020" from 03.04.2020]. (2020). Vidomosti Verkhovnoi Rady Ukrainy - Bulletin of Verkhovna Rada of Ukraine, 5, Art. 31. Retrieved from https://zakon.rada.gov.ua/laws/show/294-20 [in Ukrainian].

12. Mekhanizm rozpodilu dodatkovoi dotatsii na utrymannia zakladiv osvity ta okhorony zdorovia $\mathrm{v}$ oblastiakh: pohliad eksperti [The mechanism of distribution of additional subsidies for the maintenance of educational institutions and health care in regions: expert opinion]. (2018). decentralization.gov.ua. Retrieved from https://decentralization.gov.ua/news/8790 [in Ukrainian].

13. Samokhin, I. (n.d.). Demohrafichna kryza ta nerivnist v ukrainskii shkilnii systemi. Shkilna karta Ukrainy [Demographic crisis and inequality in the Ukrainian school system. School map of Ukraine]. cedos.org.ua. Retrieved from https://cedos.org.ua/edustat/graph [in Ukrainian].

14. Education and Training. Key competences and basic skills. (2018). ec.europa.eu. Retrieved from https://ec.europa.eu/education/policy/school/competences_en [in English].

15. Adult education level. (2018). data.oecd.org. Retrieved from http://data.oecd.org/eduatt/adult-education-level.htm [in English].

16. Yedynyi veb-portal orhaniv vykonavchoi vlady Ukrainy [The only web portal of the executive authorities of Ukraine]. www.kmu.gov.ua. Retrieved from https://www.kmu.gov.ua [in Ukrainian].

17. Zahalna informatsiia [General information]. decentralization.gov.ua. Retrieved from https://decentralization.gov.ua/about [in Ukrainian].

18. Rishennia Kyivskoi oblasnoi rady "Pro oblasnyi biudzhet Kyivskoi oblasti na 2019 rik" : vid 20.12.2018 № 530-25-VII [Decision of the Kyiv Regional Council "On the Regional Budget of the Kiev Region for 2019” from 20.12.2018, № 530-25-VII]. koda.gov.ua. Retrieved from http://koda.gov.ua/oblderzhadministratsija/publichna-informatsiya/byudzhet-kiivskoioblasti/rishennya-pro-oblasniy-byudzhet-kiivsk/2019-rik/ [in Ukrainian].

19. Metodychni rekomendatsii shchodo stvorennia systemy upravlinnia osvitoiu obiednanykh terytorialnykh hromad [Guidelines for the establishment of a unified territorial community education management system]. (2016). old.decentralization.gov.ua. Retrieved from https://old.decentralization.gov.ua/pics/attachments/2016-02-22-1.pdf [in Ukrainian]. 
20. Rozporiadzhennia Holovy Kyivskoi oblasnoi administratsii "Pro skhvalennia proiektu rishennia Kyivskoi oblasnoi rady "Pro oblasnyi biudzhet Kyivskoi oblasti na 2020 rik" : vid 22.11.2019, № 678 [Order of the Head of the Kyiv Regional Administration "On approval of the draft decision of the Kyiv Regional Council "On the Regional Budget of the Kyiv Region for 2020" from 22.11.2019, № 678]. koda.gov.ua. Retrieved from http://koda.gov.ua/normdoc/proskhvalennya-proiektu-rishennya-kiivs/ [in Ukrainian].

21. Zakon Ukrainy "Pro mistseve samovriaduvannia v Ukraini” : vid 21.05.1997 № 280/97-VR [Law of Ukraine "On Local Self-Government in Ukraine" from May 21, 1997, № 280/97-VR]. (1997). Vidomosti Verkhovnoi Rady Ukrainy - Bulletin of Verkhovna Rada of Ukraine, 24. Art. 170. Retrieved from https://zakon.rada.gov.ua/laws/show/280/97-0 $\% 0 \% \mathrm{~B} 2 \% \mathrm{D} 1 \% 80$ [in Ukrainian]. 